УдК 330.34

\title{
ЦИФРОВІЗАЦІЯ БІЗНЕС-ПРОЦЕСІВ ПРОМИСЛОВИХ ПІДПРИЕМСТВ
}

\section{DIGITALIZATION OF BUSINESS PROCESSES OF INDUSTRIAL ENTERPRISES}

\author{
Зуб Парасковія Василівна \\ студентка, \\ Університет державної фріскальної служби України \\ ORCID: https://orcid.org/0000-0001-8907-3537 \\ Калач Ганна Миколаївна \\ кандидат економічних наук, доцент, \\ Університет державної фріскальної служби України \\ ORCID: https://orcid.org/0000-0002-6031-0591 \\ Zub Paraskoviia, Kalach Hanna \\ University of the Fiscal Service of Ukraine
}

\begin{abstract}
Стаття присвячена дослідженню процесів цифрової трансформації бізнесу. Розглянуто основні елементи цифрових перетворень: робота з клієнтами, операційні бізнес-процеси та бізнес-моделі підприємства та наведено їх характеристику. Проаналізовано способи та основні етапи проведення цифровізації бізнес-процесів промислового підприємства. Визначено, що методологія цифровізації бізнес-процесів підприємства базується на опорних концепціях інфрормаційних систем, які еволюціонували. Цифровізація найбільше впливає на такі складові бізнес-процесів як: взаємодія з клієнтами, вартісна пропозиція та управління внутрішньою інорраструктурою. Охарактеризовано найбільш розповсюджені елементи інтегрованого інформаційного середовища, що використовують промислові підприємства для автоматизації усіх бізнес-процесів. Запропоновано промисловим підприємствам розробити власні карти цифрових трансформацій, що дозволить сконцентрувати ресурси на найбільш перспективних напрямах розвитку.

Ключові слова: промислове підприємство, цифровізація бізнес-процесів, етапи цифровізації, інформаційне середовище, цифрова трансформація.

Статья посвящена исследованию процессов цифровой трансформации бизнеса. Рассмотрены основные элементы циорровых преобразований: работа с клиентами, операционные бизнес-процессы и бизнес-модели предприятия и приведены их характеристики. Проанализированы способы и основные этапы цифровизации бизнес-процессов промышленного предприятия. Определено, что методология цифровизации бизнес-процессов предприятия базируется на опорных концепциях информационных систем, которые эволюционировали. Цифровизация больше всего влияет на такие составляющие бизнес-процессов как: взаимодействие с клиентами, ценовое предложение и управление внутренней инфраструктурой. Охарактеризованы наиболее распространенные элементы интегрированной информационной среды, которые используют промышленные предприятия для автоматизации бизнес-процессов. Предложено промышленным предприятиям разработать собственные карты цифровых трансформаций, что позволит сконцентрировать ресурсы на наиболее перспективных направлениях развития.
\end{abstract}

Ключевые слова: промышленное предприятие, цифровизация бизнес-процессов, этапы цифровизации, информационная среда, цифрровая трансформация.

Problem. Digitalization of industry is an integral part of the National Economic Strategy. This requires the transformation of traditional business processes of industrial enterprises, analysis of the components of digitalization, determining the stages of its implementation, development of recommendations for planning and systematization of digitalization processes. Purpose. Identify and describe the elements of digitalization of business processes of industrial enterprises, methods and procedure for implementing digitalization measures in modern conditions, to develop successive stages of business process transformation, to propose a method that will allow to systematize measures for business process transformation. Research methods. In the process of research the economic method was used to study the trends of industry digitalization, the method of system analysis was used to identify the struc- 
tural elements of the digitization of business processes. We used methods of comparison, analogy and systematization, a comprehensive review of academic literature. Research results. The main elements of digital transformations are considered: work with clients, operational business processes and business models of the enterprise and their characteristic is resulted. The methods and main stages of digitalization of business processes of an industrial enterprise are analyzed. It is determined that the methodology of digitalization of business processes of the enterprise is based on the basic concepts of information systems that have evolved. Digitalization has the greatest impact on such components of business processes as: interaction with customers, value proposition and internal infrastructure management. The most common elements of the integrated information environment used by industrial enterprises to automate all business processes are described. Recommendations. The practical value of the article is to structure the elements of business digitalization, which will allow companies to systematically approach the transformation of business processes. Industrial enterprises are invited to develop maps of digital transformations, which will allow concentrating resources on the most promising areas of development.

Keywords: industrial enterprise, digitalization of business processes, stages of digitalization, information environment, digital transformation.

Постановка проблеми. Головним глобальним трендом останніх років являється цифрровізація, яка стосується усіх сорер економіки та суспільного життя. Нині передові технології Індустрії 4.0 (зокрема хмарні, біотехнології, засоби збору та аналізу «Big Data», 3D-друк, краудсорсинг, технології «Blockchain») кардинально змінюють більшість галузей економіки. Вітчизняні науковці акцентують увагу на тому, що з'являється цілковито новий тип промислового виробництва, який базується на повній автоматизації виробничих процесів, технологіях доповненої реальності, великих масивах даних та Інтернеті речей. Саме тому в теперішніх реаліях цисрровізація розглядається науковцями, економістами-практиками та урядовцями як важливий драйвер соціально-економічного розвитку як країни, галузі економіки, так і окремого підприємства. Коли почали розвиватися цисрові платсрорми, то очікувалось, що вони дозволять зменшити транзакційні витрати для учасників платформи і створять умови для масштабування бізнесу. Зменшення трансакційних витрат забезпечується за рахунок таких переваг як мобільність, зручність, швидкість, низька вартість обслуговування, візуалізація [1, с. 27]. Питання цифровізації стали предметом обговорення світовими лідерами на саміті G20 у м. Осака (Японія), на якому визначено головні пріоритети, серед яких зокрема підтримка цифровізації мікро-, малих та середніх підприємств [3, с. 11]. Циорровізація може стати каталізатором для створення 700 тис. додаткових робочих місць в Україні (без урахування експортної індустрії) [8]. Таким чином, дослідження тенденцій циорровізації $\epsilon$ актуальною економічною проблемою, особливо це важливо для промислових підприємств України, бізнес-процеси яких потребують якісної транссрормації.

Аналіз останніх досліджень і публікацій. Проблематику цифрової трансформа- ції бізнес-процесів підприємств та їх бізнесмоделей розглядали у своїх працях зарубіжні та вітчизняні науковці, зокрема: Л. Лазебник, Л. Федулова, Г. Берг, Б. Соліс, В. Ткачук та ін. Навіть не зважаючи на наявні вагомі наукові здобутки, кардинальні зміни зовнішніх умов господарювання під впливом пандемії коронавірусу актуалізують потребу подальшого дослідження питань цифровізації бізнес-процесів промислових підприємств як основи забезпечення їх конкурентоспроможності та ефективності діяльності.

Формулювання цілей статті. Мета написання статті - охарактеризувати елементи цифрровізації бізнес-процесів промислових підприємств, способи та процедуру впровадження заходів цисрровізації в сучасних умовах.

Виклад основного матеріалу. Процес цифррової транссрормації бізнесу включає декілька самостійних взаємопов'язаних елементів. Згідно 3 баченням науковців Центру цифрової трансфрормації бізнесу, такими елементами або ж ключовими областями цифрових перетворень виступають: робота 3 клієнтами, операційні бізнес-процеси та бізнес-моделі підприємства. В свою чергу, кожен із зазначених елементів поділяється на складові частини, опис яких наведено у табл. 1.

Безумовно, що значне покращення діяльності промислового підприємства потребує успішного проведення цифровізації в кожній із окреслених в табл. 1 складовій загальної моделі. Проведення цифровізації відкриє для підприємства безліч перспектив для розвитку та зростання. Зокрема, використання цифррових платсрорм дозволить спростити виконання операцій, ссрормувати сучасні мережі зв'язків й обміну інорормацією. Цифррова трансфрормація всіх сфер і ринків також може сприяти зростанню якості промислових товарів і послуг при одночасному значному скороченні витрат. Окрім цього, цифровізація 
Таблиця 1

Модель структуризації елементів цифрової трансформації бізнесу

\begin{tabular}{|c|c|c|}
\hline $\begin{array}{l}\text { № } \\
\text { ח/n }\end{array}$ & $\begin{array}{c}\text { Назва елемента } \\
\text { моделі }\end{array}$ & Коротка характеристика \\
\hline \multirow{3}{*}{1} & \multirow{3}{*}{ Робота з клієнтами } & $\begin{array}{l}\text { 1. Більш глибоке розуміння клієнтів - реалізується завдяки } \\
\text { використанню підприємством соціальних мереж в цілях вивчення } \\
\text { вимог і вподобань клієнтів, просування бренду, надання підтримки } \\
\text { клієнтам під час придбання та використання продукції тощо. }\end{array}$ \\
\hline & & $\begin{array}{l}\text { 2. Зріст виручки від наявних у підприємства клієнтів - статистичні } \\
\text { дані про покупки власних клієнтів використовуються в цілях } \\
\text { організації персоналізованих продажів і повного обслуговування } \\
\text { клієнтів, розробки індивідуальних пакетів пропозицій. } \\
\end{array}$ \\
\hline & & $\begin{array}{l}\text { 3. Пошук нових точок взаємодії з клієнтами - реалізується } \\
\text { шляхом створення за допомогою цифрових технологій } \\
\text { можливостей для власних клієнтів для самообслуговування, або } \\
\text { ж багатоканальних способів доступу до клієнтів. } \\
\end{array}$ \\
\hline \multirow{3}{*}{2} & \multirow{3}{*}{ Операційний процес } & $\begin{array}{l}\text { 1. Автоматизація виробничих процесів, що дозволяє } \\
\text { підприємствам переорієнтуватися на вирішення стратегічних } \\
\text { задач, підвищити рівень безпеки праці. }\end{array}$ \\
\hline & & $\begin{array}{l}\text { 2. Реалізація творчого потенціалу співробітників - впровадження } \\
\text { циоррових технологій дозволяє скоротити рутинну роботу та } \\
\text { підвищити есрективність праці, налагодити роботу без фрізичної } \\
\text { прив'язку до робочого місця, налагодити взаємодію між } \\
\text { працівниками незалежно від їх місцезнаходження. }\end{array}$ \\
\hline & & $\begin{array}{l}\text { 3. Управління продуктивністю, базуючись на результатах аналізу } \\
\text { «Великих даних». Новітні циоррові системи надають керівництву } \\
\text { можливість приймати управлінські рішення, опираючись на } \\
\text { фрактичні дані в режимі реального часу, а також здійснювати } \\
\text { порівняння поточних процесів й перерозподіляти виробничі } \\
\text { потужності найбільш оптимальним чином. }\end{array}$ \\
\hline \multirow{3}{*}{3} & \multirow{3}{*}{ Бізнес-модель } & $\begin{array}{l}\text { 1. Точкове впровадження нових технологій лише в окремі бізнес- } \\
\text { процеси, без повної зміни бізнес-моделі підприємства. }\end{array}$ \\
\hline & & $\begin{array}{l}\text { 2. Введення нових цифррових бізнес-моделей, що також включає } \\
\text { перебудову бізнес-процесів згідно з вимогами цифровізації. }\end{array}$ \\
\hline & & $\begin{array}{l}\text { 3. Цифрова глобалізація - структурована інформація та цифрові } \\
\text { технології дозволяють підприємствам отримати глобальний } \\
\text { синергетичний ефект, зберігши при цьому здатність реагувати на } \\
\text { локальні зміни. }\end{array}$ \\
\hline
\end{tabular}

Джерело: побудовано автором за [2]

сприяє розвитку інновацій, перетворює ланцюжки створення вартості, відкриваючи при цьому нові можливості для збільшення доданої вартості [4, с. 7].

Важливою складовою цисррової транссрормації промислових підприємств $є$ цифровізація їх бізнес-процесів. Зазначимо, що під цим терміном вітчизняні науковці розглядають як автоматизацію основних і допоміжних (забезпечувальних, підтримуючих) бізнес-процесів, так і бізнес-процесів управління, що проводиться в цілях їх оптимізації та забезпечення еорективності діяльності підприємства та галузі в цілому [4, с. 20]. Згідно результатів досліджень, проведених компанією Ernst \& Young, цифровізація найбільше впливає на такі складові бізнес-процесів як: взаємодія 3 клієнтами, вартісна пропозиція та управління внутрішньою індрраструктурою [5]. Виходячи із фрактичного стану процесів підприємства та його фрінансових і кадрових можливостей цифровізація бізнес-процесів може проводитись із використанням одного із способів, котрі наведено на рис. 1. Цифровізація бізнес-процесів промислових підприємств шляхом впровадження цифррових технологій сприяє фрормуванню більш досконалих бізнес-процесів, що в свою чергу, призводить до покращення їх ефрективності, гнучкості, адаптивності до змін зовнішнього середовища та срормування конкурентних переваг.

Цифровізація бізнес-процесів підприємства передбачає послідовне виконання декількох етапів, що відображені на рис. 2.

Відзначимо, що методологія циорровізації бізнес-процесів підприємства базується на 




Рис. 1. Головні способи проведення цифровізації бізнес-процесів підприємства Джерело: побудовано автором за [7]

опорних концепціях інформаційних систем, які в своєму розвитку еволюціонували так: MRP I (Material Requirements Planning) - MRP II (Manufacturing Resource Planning) - ERP-систем підприємства (Enterprise Requirements Planning) - CSRP (Customer Synchronized Resource Planning). Сучасна ERP-система являє собою комплекс взаємозалежних модулів (додатків), які забезпечують роботу єдиного інтегрованого інформаційного середовища за рахунок автоматизації усіх бізнес-процесів підприємства. Нині в Україні серед підприємств стає поширеним такий вітчизняний програмний продукт як ERP-система IT-Enterprise корпорації «Інфрормаційні технології». Ця система має комплексні проекти впровадження «Industry 4.0» на підприємствах ссрери промисловості (металургії, машинобудівної, харчової, хімічної, кабельної) та сільського господарства, включаючи вве- дення систем керування виробництвом, контролінгом, логістикою, бюджетуванням тощо. Всі модулі системи IT-Enterprise умовно групуються в контури управління, а саме такі як: виробництвом та технічною підготовкою виробництва, проєктами, основними виробничими засобами, бізнес-процесами та документообігом, персоналом, логістика, бюджетування й контролінг. ERP-система IT-Enterprise складається 3 багатьох модулів, кожен з яких автоматизує певні завдання [4, с. 20-21].

Цисрровізація бізнес-процесів підприємства включає ряд елементів, коротку характеристику основних з них наведено у табл. 2.

У Національній економічній стратегії на період до 2030 р. визначено такі вектори економічного розвитку у сорері цифрровізації:

- розробити та впровадити карти цифрових трансорормацій 7-10 галузей, які потен-

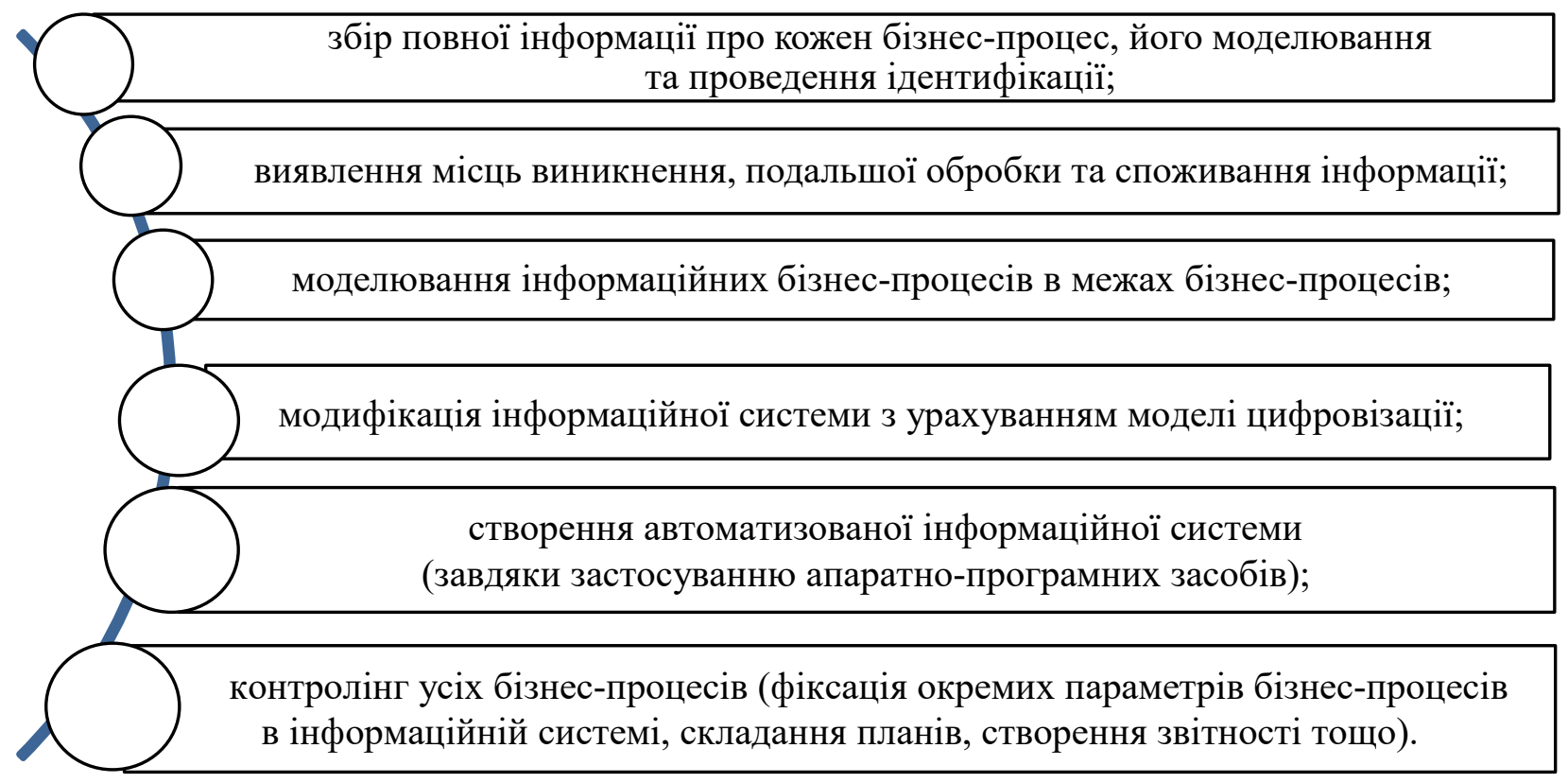

Рис. 2. Послідовність реалізації заходів щодо цифровізації бізнес-процесів промислових підприємств

Джерело: побудовано автором за [4, с. 20] 
Таблиця 2

Характеристика елементів цифровізації бізнес-процесів підприємства

\begin{tabular}{|c|c|c|}
\hline $\begin{array}{c}\text { № } \\
\text { ח/ח }\end{array}$ & $\begin{array}{c}\text { Назва } \\
\text { елемента }\end{array}$ & Коротка характеристика елемента \\
\hline 1 & Реалізація & $\begin{array}{l}\text { Забезпечення успішної реалізації стратегії підприємства потребує } \\
\text { проведення ґрунтовного аналізу ринку та конкурентів. }\end{array}$ \\
\hline 2 & Результат & $\begin{array}{l}\text { Завершенням цього етапу буде обґрунтоване рішення про те, } \\
\text { чи потрібно переходити до цифррової трансфрормації чи ні. }\end{array}$ \\
\hline 3 & Аналіз & $\begin{array}{l}\text { Слід провести ґрунтовний аналіз того, що підприємства можуть } \\
\text { краще виконувати з наявними бізнес-процесами і які бізнес-процеси } \\
\text { потребують негайного впровадження новітніх технологій. }\end{array}$ \\
\hline 4 & Визнання & $\begin{array}{l}\text { Підприємствам потрібно визначити ті зміни, які вони можуть } \\
\text { впровадити в бізнес-процеси задля їх покращення. Для цього треба } \\
\text { виконати безліч дій, зокрема таких: вивчити діючі бізнес-процеси; } \\
\text { залучити ключових стейкхолдерів; вивчити новітні інноваційні } \\
\text { технології; обрати технології та технічні продукти, які можна } \\
\text { впровадити в діяльність підприємства; переглянути та покращувати } \\
\text { продукцію, сервісні пропозиції та навіть бізнес-модель. }\end{array}$ \\
\hline 5 & $\begin{array}{l}\text { Розстановка } \\
\text { пріоритетів }\end{array}$ & $\begin{array}{l}\text { Підприємствам спочатку треба переосмислити виявлені зміни, } \\
\text { проаналізувати витрати та вигоди, оцінити можливості, ресурси, } \\
\text { бюджети тощо, а потім на підставі цього розставити пріоритети. }\end{array}$ \\
\hline 6 & Впровадження & $\begin{array}{l}\text { Реалізація змін. Включає отримання потрібних бюджетів, визначення } \\
\text { відповідальних груп, перепроєктування процесів і реалізацію } \\
\text { з використанням ідентифікованих технологій і технічних продуктів. }\end{array}$ \\
\hline 7 & Розгортання & $\begin{array}{l}\text { Полягає в тому, щоб зробити нову систему доступною } \\
\text { для використання. Включає розробку чіткого плану розгортання } \\
3 \text { чітко визначеними фуунціями, обов'язками та термінами. }\end{array}$ \\
\hline
\end{tabular}

Джерело: побудовано автором за [6; 7]

ційно можуть показати значне зростання за період 3-5 років;

- запровадити пакет стимулів для створення в країні високотехнологічних виробництв (так звані «смарт-срабрики», Індустрія 4.0.);

- впровадження системи інвестиційних конкурсів (для державних промислових підприємств та концесійних моделей);

- реалізація програм «Україна - цифровий коридор» та «Україна - Data Elysium» [8].

Висновки із цього дослідження і дальші перспективи в цьому напрямку. Проведення цифровізації бізнес-процесів промислових підприємств $€$ важливим і актуальним кроком, який виступає драйвером до кардинальних змін в поточній діяльності та розвитку підприємства. Перед прийняттям управлінського рішення про цифррову трансформацію бізнес-процесів потрібно ретельно проаналізувати діючі бізнес-процеси підприємства, зрозуміти проблеми та можливості до їх вирішення, й лише потім обрати способи та заходи цисрровізації наявних бізнес-процесів, або ж розробки принципово нових на базі цисррових технологій та платформ. Для того, щоб визначити, які саме підприємства та галузі є потенційно спроможними для реалізації поставлених у Національній стратегії цілей, потрібно провести міжгалузевий аналіз стану цифровізації бізнес процесів на промислових підприємствах, а на рівні підприємства доцільно розробити власні карти циоррових трансфрормацій, що дозволить систематизувати заходи та сконцентрувати ресурси на найбільш перспективних напрямах розвитку.

\section{СПИСОК ВИКОРИСТАНИХ ДЖЕРЕЛ:}

1. Калач Г.М. Моделі оцінки бренду в умовах цифровізації бізнесу. Підприємництво і торгівля : збірник наукових праць. 2020. Вип. 27. С. 26-30.

2. Звіт Глобального центру з цисрової трансформації бізнесу: Digital Vortex. How Digital Disruption Is Redefining Industries. URL: https://www.cisco.com/c/dam/en/us/solutions/collateral/industry-solutions/digital-vortexreport.pdf (дата звернення: 05.05.2021).

3. Федулова Л. Тенденції розвитку та впровадження цифрових технологій для реалізації цілей сталого розвитку. Економіка природокористування і сталий розвиток. Київ : ДУ ІЕПСР НАН України, 2020. № 7(26). C. 6-14. URL: http://dspace.nbuv.gov.ua/handle/123456789/166840 (дата звернення: 10.05.2021). 
4. Лазебник Л.Л., Войтенко В.О. Інформаційна інфраструктура в цифровізації бізнес-процесів підприємства. Науковий вісник Міжнародного гуманітарного університету. 2020. Випуск 42. С. $18-22$. URL: http://www.vestnik-econom.mgu.od.ua/journal/2020/42-2020/5.pdf (дата звернення: 16.04.2021).

5. Лісова Р.М. Вплив діджиталізації на бізнес-моделі: етапи та інструменти цифрової трансформації. Науковий вісник Ужгородського національного університету. Серія : Міжнародні економічні відносини та світове господарство. 2019. Вип. 24(2). С. 114-118. URL: http://nbuv.gov.ua/UJRN/Nvuumevcg_2019_24\% 282\%29_24 (дата звернення: 16.04.2021).

6. Солис Б. Состояние цифрровой трансформации в 2017 году. URL: https://www.prophet.com/wp-content/ uploads/2018/04/Altimeter-_-2017-State-of-DT.pdf (дата звернення: 20.05.2021).

7. Gerbert van den Berg, Paul Pietersma Key Management Models. The 75+ models every manager needs to know. Pearson. 2015. 326 p.

8. Національна економічна стратегія 2030. URL: http:https://nes2030.org.ua/ (дата звернення: 26.05.2021).

\section{REFERENCES:}

1. Kalach H.M. (2020) Modeli otsinky brendu v umovakh tsyfrovizatsii biznesu. Pidpryiemnytstvo $i$ torhivlia: zbirnyk naukovykh prats, vol. 27, pp. 26-30.

2. Zvit Hlobalnoho tsentru z tsyfrovoi transformatsii biznesu: Digital Vortex. How Digital Disruption Is Redefining Industries. URL: https://www.cisco.com/c/dam/en/us/solutions/collateral/industry-solutions/digital-vortex-report.pdf (accessed 05 May 2021).

3. Fedulova L. (2020) Tendentsii rozvytku ta vprovadzhennia tsyfrovykh tekhnolohii dlia realizatsii tsilei staloho rozvytku. Ekonomika pryrodokorystuvannia i stalyi rozvytok. Kyiv: DU IEPSR NAN Ukrainy, no. 7(26), pp. 6-14. URL: http://dspace.nbuv.gov.ua/handle/123456789/166840 (accessed 10 May 2021).

4. Lazebnyk L.L., Voitenko V.O. (2020) Informatsiina infrastruktura v tsyfrovizatsii biznes-protsesiv pidpryiemstva. Naukovyi visnyk Mizhnarodnoho humanitarnoho universytetu, vol. 42, pp. 18-22. URL: http://www.vestnik-econom. mgu.od.ua/journal/2020/42-2020/5.pdf (accessed 16 April 2021).

5. Lisova R.M. (2019) Vplyv didzhytalizatsii na biznes-modeli: etapy ta instrumenty tsyfrovoi transformatsii. Naukovyi visnyk Uzhhorodskoho natsionalnoho universytetu. Seriia: Mizhnarodni ekonomichni vidnosyny ta svitove hospodarstvo, vol. 24(2), pp. 114-118. URL: http://nbuv.gov.ua/UJRN/Nvuumevcg_2019_24\%282\%29_24 (accessed 16 April 2021).

6. Solys B. Sostoianye tsyfrovoi transformatsyy v 2017 hodu. URL: https://www.prophet.com/wp-content/ uploads/2018/04/Altimeter-_-2017-State-of-DT.pdf (accessed 20 May 2021).

7. Gerbert van den Berg, Paul Pietersma Key Management Models. The 75+ models every manager needs to know. Pearson. 2015. 326 p.

8. Natsionalna ekonomichna stratehiia 2030. URL: http:https://nes2030.org.ua/ (accessed 26 May 2021). 